\title{
Electrochemical and Spectroscopic Studies of Tungstencarbonyl Complexes Containing Nitrogen and Phosphorous Ligands
}

\author{
Paula S. Haddad, Gislaine Miranda, Sandra R. Ananias, Antonio E. Mauro* and Vânia M. Nogueira* \\ Instituto de Química de Araraquara, Universidade Estadual Paulista, CP 355, 14801-970, Araraquara - SP, Brazil
}

\begin{abstract}
Este trabalho tratou da síntese, caracterização espectroscópica e do comportamento eletroquímico dos compostos $\left[\mathrm{W}(\mathrm{CO})_{4}(\right.$ bipy $\left.)\right](\mathbf{1}),\left[\mathrm{W}(\mathrm{CO})_{3}(\right.$ bipy $\left.)(\mathrm{dppm})\right](\mathbf{2})$ e $\left[\mathrm{W}(\mathrm{CO})_{3}(\right.$ bipy $\left.)(\mathrm{dppf})\right](\mathbf{3})$, bipy = 2,2'-bipiridina; $\mathrm{dppm}=$ bis(difenilfosfina) metano; $\mathrm{dppf}=1,1^{\prime}$ '-bis(difenilfosfina)ferroceno. Os dados provenientes das espectroscopias no infravermelho e de $\mathrm{RMN}{ }^{31} \mathrm{P}\left\{{ }^{1} \mathrm{H}\right\}$ mostraram que o tungstênio apresenta uma geometria de coordenação octaédrica com as fosfinas atuando como ligantes monodentados. Os estudos eletroquímicos foram realizados empregando-se as técnicas de voltametria cíclica e coulometria a potencial controlado. Os voltamogramas cíclicos mostraram que os carbonil complexos contendo ligantes fosforados apresentam uma maior estabilidade frente à oxidação do que o composto (1).
\end{abstract}

The present work deals with the synthesis, spectroscopic investigation and electrochemical behaviour of the compounds $\left[\mathrm{W}(\mathrm{CO})_{4}(\right.$ bipy $\left.)\right](\mathbf{1}),\left[\mathrm{W}(\mathrm{CO})_{3}(\right.$ bipy $\left.)(\mathrm{dppm})\right](\mathbf{2})$ and $\left[\mathrm{W}(\mathrm{CO})_{3}\right.$ (bipy)(dppf)] (3), bipy = 2,2'-bipyridine; dppm = bis(diphenylphosphino)methane; dppf $=1,1^{\prime}$-bis(diphenylphosphino)ferrocene. The IR and ${ }^{31} \mathrm{P}\left\{{ }^{1} \mathrm{H}\right\}$ NMR spectroscopic data have shown an octahedral coordination geometry for the tungsten atom with the diphosphines acting as monodentate ligands. The electrochemical behaviour of the complexes was investigated by cyclic voltammetry and controlled potential coulometry. Cyclic voltammograms have indicated that the compounds containing diphosphines ligands are more stable towards oxidation than compound (1).

Keywords: tungstencarbonyl complexes, diphosphines, cyclic voltammetry, infrared spectroscopy

\section{Introduction}

The chemistry of metal carbonyls has been of considerable interest for several decades mainly due to structural aspects and reactivity of these compounds in respect to several classes of organic ligands, and also by their interesting applications in catalysis and in electronic devices based on non linear optical effects ${ }^{1-4}$.

Carbonyl complexes of the Group 6 which contain nitrogen and phosphorous ligands exhibit an interesting and varied chemistry ${ }^{5-7}$. Reports on 2,2' - bipyridine (bipy) substituted tetracarbonyls and tricarbonyls phosphine complexes and their structural investigation emerged from literature many years ago ${ }^{8}$. It is worthy to note that the elec-

e-mail: mauro@iq.unesp.br; vaniamn@iq.unesp.br

Presented at the XI Simpósio Brasileiro de Eletroquímica e Eletroanalítica, Maragogi - AL, Brazil, April 5-9, 1999. Guest editor: Luis Alberto Avaca.

This work is dedicated to the memory of Prof. Waldemar Saffioti. trochemical redox reactions and the kinetics and mechanism of the ligands substitution in these octahedral complexes have always attracted interest of several organometallic research groups. In this way, electrochemical studies 9 developed on the oxidative redox chemistry of 18 electron carbonyl derivatives of Group 6 and 7 transition metals have shown that the first oxidative step is a one-electron process and that the subsequent chemistry of the systems depends on the stability and reactivity of the oxidation product. Isomerization of the resulting 17 electron species is therefore a common phenomenon, but when this is not possible disproportionation is often observed.

The reasons for carrying out the present work are concerned to our interest to study the physical and chemical properties of metalcarbonyl complexes, which leads to possible applications in catalysis. This can be accomplished by immobilization of the compounds on the surface of inorganic supports such as organofunctionalized silica gel $^{1,10-11}$. So we describe in this paper the preparation, spectroscopic characterization by IR and ${ }^{31} \mathrm{P}\left\{{ }^{1} \mathrm{H}\right\}$ NMR 
spectroscopies and electrochemical properties of the complexes $\left[\mathrm{W}(\mathrm{CO})_{4}(\right.$ bipy $\left.)\right](\mathbf{1}),\left[\mathrm{W}(\mathrm{CO})_{3}(\right.$ bipy $\left.)(\mathrm{dppm})\right](\mathbf{2})$ and $\left[\mathrm{W}(\mathrm{CO})_{3}\right.$ (bipy)(dppf)] (3), bipy = 2,2'-bipyridine; dppm = bis(diphenylphosphino)methane; $\mathrm{dppf}=1,1$ ' bis(diphenylphosphino)ferrocene.

\section{Experimental}

\section{Synthesis and characterization of the complexes}

All reactions were routinely performed under an atmosphere of pure dry nitrogen using standard Schlenk techniques. Solvents were purified and dried by specific methods ${ }^{12}$. The reagents $\left[\mathrm{W}(\mathrm{CO})_{6}\right], \mathrm{Me}_{3} \mathrm{NO} .2 \mathrm{H}_{2} \mathrm{O}$, bipy, dppm and dppf were supplied by Aldrich and used without further purification. The infrared spectra were recorded on a Nicolet IMPACT 400 spectrophotometer in the wavelength range from 4000 to $400 \mathrm{~cm}^{-1}$, at a resolution of $4 \mathrm{~cm}^{-1}$, as $\mathrm{KBr}$ pellets. The ${ }^{31} \mathrm{P}\left\{{ }^{1} \mathrm{H}\right\}$ NMR spectra were obtained as $\mathrm{CHCl}_{3}\left(\mathrm{D}_{2} \mathrm{O}\right.$ capillar) solution and referred to the $85 \%$ $\mathrm{H}_{3} \mathrm{PO}_{4}$ standard on a Brucker AC-200 spectrometer.

The compounds $\mathbf{1}$ and $\mathbf{2}$ were prepared as previously described $^{8,13}$. The results of $\mathrm{C}, \mathrm{H}$ and $\mathrm{N}$ elemental analysis were in agreement with the formulae. (1): Found: $\mathrm{C}$, 31.23; $\mathrm{H}, 1.34 ; \mathrm{N}, 6.00$, \%. Calc. for $\mathrm{C}_{14} \mathrm{H}_{8} \mathrm{~N}_{2} \mathrm{O}_{4} \mathrm{~W}: \mathrm{C}, 31.85$; H, 1.34; N, 6.19, \%. 2: Found: C, 55.93; H, 3.59; N, 3.43, \%. Calc. for $\mathrm{C}_{38} \mathrm{H}_{30} \mathrm{~N}_{2} \mathrm{O}_{3} \mathrm{P}_{2} \mathrm{~W}$ : C, 56.45; H, 3.74; N, $3.47 \%$.

The preparation of $\mathbf{3}$ was as follows: a solution $(0.960 \mathrm{mmol})$ of trimethylamine $\mathrm{N}$-oxide (TMNO) in $5 \mathrm{~mL}$ of ethanol was added to an acetonitrile solution $(25 \mathrm{~mL})$ of the compound $1(0.640 \mathrm{mmol})$, followed by the addition of dppf $(0.640 \mathrm{mmol})$. The mixture was stirred for $22 \mathrm{~h}$ at room temperature. The resulting orange precipitate was isolated by filtration under $\mathrm{N}_{2}$, washed with diethyl ether and dried in vacuum. Found: C, 56.82; H, 3.51; N, 2.87, \%. Calc. for $\mathrm{C}_{47} \mathrm{H}_{38} \mathrm{~N}_{2} \mathrm{O}_{3} \mathrm{P}_{2} \mathrm{FeW}$ : C, 57.69; H, 3.71; N, 2.86, \%.

\section{Electrochemicalmeasurements}

The cyclic voltammograms and the coulometric investigation were performed with a PAR Model 273 A potentiostat/galvanostat equipped with a $\mathrm{X}-\mathrm{Y}$ recorder.
All electrochemistry tests were carried out using conventional three electrode cell.

A platinum disk was used as the working electrode in the cyclic voltammetry experiments and a platinum gauze in the controlled potential electrolysis. $\mathrm{An}_{\mathrm{Ag}} 0 / \mathrm{Ag}^{+}$ $\left(\mathrm{AgClO}_{4} 1.0 \times 10^{-2} \mathrm{~mol} \mathrm{~L}^{-1}, 0.50 \mathrm{~mol} \mathrm{~L}^{-1} \mathrm{NaClO}_{4}, \mathrm{DMF}\right)$ electrode was used as the reference electrode and a platinum wire as the auxiliary electrode. Sodium perchlorate (Merck, p.a.) was recrystallized in ethanol (p.a.), dried at $110^{\circ} \mathrm{C}$ for $24 \mathrm{~h}$ and further used as the supporting electrolyte. All the solutions $\left(1.0 \times 10^{-3} \mathrm{~mol} \mathrm{~L}^{-1}\right)$ were purged with high purity argon, presaturated with the blank solution before each experiment. In the potential range of interest $(-0.8$ to $+1.0 \mathrm{~V})$, no electroative species were observed in the absence of tungsten complexes.

\section{Results and Discussion}

\section{IR and ${ }^{31} P\left\{{ }^{1} H\right\} N M R$ data}

The reaction of $\left[\mathrm{W}(\mathrm{CO})_{4}(\right.$ bipy) $]$ (1) with the diphosphines provided the elimination of one $\mathrm{CO}$ molecule affording compounds of general formula $\left[\mathrm{W}(\mathrm{CO})_{3}\right.$ (bipy) $\left.(\mathrm{P}-\mathrm{P})\right], \mathrm{P}-\mathrm{P}=\mathrm{dppm}$ (2), dppf (3), which affords a polyhedron with an octahedral coordination around the tungsten centre.

Spectroscopic data (IR and ${ }^{31} \mathrm{P}\left\{{ }^{1} \mathrm{H}\right\} \mathrm{NMR}$ ) are summarized in Table 1.

In general, the $\mathrm{CO}$ stretching vibrations allow a clear identification of the geometry around the metallic centers.

$\left[\mathrm{W}(\mathrm{CO})_{6}\right], \mathbf{1}, \mathbf{2}$ and $\mathbf{3}$ are all molecules with an octahedral geometry. However in this series of compounds there is a lowering of symmetry as the $\mathrm{CO}$ groups of [ $\left.\mathrm{W}(\mathrm{CO})_{6}\right]$ are substituted by other ligands and consequently the IR spectra of these complexes show different numbers of $v_{\mathrm{CO}}$ bands. Thus the IR spectrum of $\left[\mathrm{W}(\mathrm{CO})_{6}\right]$ shows an intense and broad $v_{\mathrm{CO}}$ band centred at $2006 \mathrm{~cm}^{-1}$, while the observation of $4 v_{\mathrm{CO}}$ bands $\left(2 \mathrm{a}_{1}+\mathrm{b}_{1}+\mathrm{b}_{2}\right)$ in the IR spectrum of $\mathbf{1}$ indicates a $\mathrm{C}_{2 \mathrm{v}}$ symmetry around the $\mathrm{W}$ atom.

Finally, the presence of three $v_{\mathrm{CO}}$ strong absorptions $\left(\mathrm{a}_{1}+\mathrm{e}\right)$ in the IR spectra of $\mathbf{2}$ and $\mathbf{3}$ suggested a facconfiguration for these complexes ${ }^{14-17}$.

Table 1. Infrared and ${ }^{31} \mathrm{P}\left\{{ }^{1} \mathrm{H}\right\}$ NMR data for the compounds $\mathbf{1}, \mathbf{2}$ and $\mathbf{3}$.

\begin{tabular}{ccc}
\hline Complexes & $v_{\mathrm{CO}}\left(\mathrm{cm}^{-1}\right)$ & $\delta(31 \mathrm{P})(\mathrm{ppm})$ \\
\hline$\left[\mathrm{W}(\mathrm{CO})_{6}\right]$ & $2006 \mathrm{~s}$ \\
{$\left[\mathrm{~W}(\mathrm{CO})_{4}(\right.$ bipy $\left.)\right]$} & $2002 \mathrm{~m}, 1906 \mathrm{~m}$, \\
& $1869 \mathrm{~s}, 1810 \mathrm{~s}$ & $2000 \mathrm{~s}, 1908 \mathrm{~s}$, \\
{$\left[\mathrm{W}(\mathrm{CO})_{3}(\right.$ bipy $\left.)(\mathrm{dppm})\right]$} & $1801 \mathrm{~m}$ & $30.0(\mathrm{~d}, \mathrm{~W} \mathrm{P}),-31.0(\mathrm{~d}, \mathrm{P}) ;$ \\
& $1999 \mathrm{~s}, 1897 \mathrm{~s}, 52 \mathrm{~Hz}, J(\mathrm{~W} \mathrm{P}) 201 \mathrm{~Hz}$ \\
{$\left[\mathrm{~W}(\mathrm{CO})_{3}(\right.$ bipy $\left.)(\mathrm{dppf})\right]$} & $1800 \mathrm{~m}$ & $50.0(\mathrm{~s}, \mathrm{~W} \mathrm{P}),-29.0(\mathrm{~s}, \mathrm{P}) ; \quad \mathrm{W} \mathrm{P}) 282 \mathrm{~Hz}(\mathrm{Pz}$ \\
\hline
\end{tabular}


The unidentate coordination mode of dppm in $\mathbf{2}$ is inferred from the presence of two mutually coupled nonequivalent phosphorous ${ }^{31} \mathrm{P}\left\{{ }^{1} \mathrm{H}\right\}$ NMR ressonances. The high field signal has a chemical shift very similar to that of the free molecule ${ }^{18}$. The downfield ressonances due to the coordinated phosphorous demonstrated a decrease in coordination shift, defined as $\delta_{\text {complex }}-\delta_{\text {free ligand }}{ }^{18}$. The ${ }^{31} \mathrm{P}\left\{{ }^{1} \mathrm{H}\right\}$ NMR spectrum of $\mathbf{3}$ is similar to that of $\mathbf{2}$; however two singlets were observed indicating that the two phosphorous atoms are not coupled due to the greater distance between them in dppf than in dppm ${ }^{19}$.

Taking these data into account we were able to propose for complexes $\mathbf{2}$ and $\mathbf{3}$ the structure represented in Scheme 1.<smiles>CC1(C(=O)O)N2CCON(CC2)C1(C=O)C(=O)O</smiles>

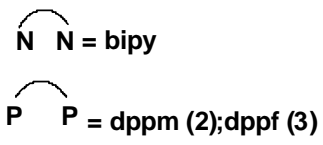

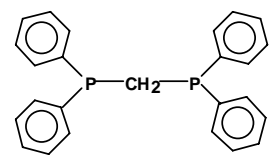

dppm

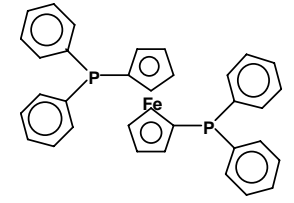

dppf
Scheme 1.

\section{Electrochemicaldata}

Figures 1, 2 and 3 show the cyclic voltammograms of compounds $\mathbf{1}, \mathbf{2}$ and $\mathbf{3}$, respectively in dimethylformamide solution $\left(1.0 \times 10^{-3} \mathrm{~mol} \mathrm{~L}^{-1}\right)$ containing $0.5 \mathrm{~mol} \mathrm{~L}^{-1} \mathrm{NaClO}_{4}$, obtained on a platinum electrode at potential scan rate $\mathrm{v}=0.050 \mathrm{~V} \mathrm{~s}^{-1}$ and $25^{\circ} \mathrm{C}$. Table 2 lists the peaks potentials for the complexes in the first scan of potentials.

The cyclic voltammogram for $\left[\mathrm{W}(\mathrm{CO})_{6}\right]$ obtained under the same conditions showed an electrochemical oxidation peak at $0.72 \mathrm{~V}\left(\mathrm{Ep}_{\mathrm{a}}{ }^{1}\right)$. The free bipy and dppm ligands do not reveal any current peak in the potential range studied. A single one-electron reversible anodic peak was observed at $0.33 \mathrm{~V}$ in the cyclic voltammogram of the ddpf compound and during the cathodic scan the reversible coupled peak was observed at $0.18 \mathrm{~V}$.

Anodic current peaks were observed for compounds 1 and 2 within the range -0.8 to $+1.0 \mathrm{~V}\left(\mathrm{vs} \mathrm{Ag}^{0} / \mathrm{Ag}^{+}\right.$), but no corresponding cathodic current peaks were observed, indicating irreversible oxidation processes. The values of
Table 2. Cyclic voltammograms data for the complexes $\left[\mathrm{W}(\mathrm{CO})_{4}(\right.$ bipy $\left.)\right] \mathbf{1},\left[\mathrm{W}(\mathrm{CO})_{3}(\right.$ bipy $\left.)(\mathrm{dppm})\right] 2$ and $\left[\mathrm{W}(\mathrm{CO})_{3}(\right.$ bipy $)$ (dppf)] 3.

\begin{tabular}{cccccccc}
\hline $\mathrm{v}$ & \multicolumn{1}{c}{$\mathbf{1}$} & \multicolumn{2}{c}{$\mathbf{3}$} \\
\hline & $\mathrm{Ep}_{\mathrm{a}}{ }^{1}$ & $\mathrm{Ep}_{\mathrm{a}}{ }^{2}$ & $\mathrm{Ep}_{\mathrm{a}}{ }^{3}$ & $\mathrm{Ep}_{\mathrm{a}}{ }^{1}$ & $\mathrm{Ep}_{\mathrm{a}}{ }^{1}$ & $* \mathrm{Ep}_{\mathrm{a}}{ }^{2}$ & $\mathrm{Ep}_{\mathrm{c}}{ }^{3}$ \\
\hline 0.025 & 0.20 & 0.50 & 0.67 & 0.23 & 0.27 & 0.55 & -0.14 \\
0.050 & 0.20 & 0.49 & 0.69 & 0.24 & 0.27 & 0.56 & -0.13 \\
0.100 & 0.19 & - & 0.65 & 0.25 & 0.27 & 0.57 & - \\
0.150 & 0.19 & - & 0.69 & 0.25 & 0.27 & 0.55 & - \\
\hline
\end{tabular}

*assigned to oxidation potential of the iron; $\mathrm{v}=\operatorname{scan}$ rate $\left(\mathrm{V} \mathrm{s}^{-1}\right)$; $\mathrm{Ep}_{\mathrm{a}}=$ anodic potential $(\mathrm{V}) ; \mathrm{Ep}_{\mathrm{c}}=$ catodic potential $(\mathrm{V})$.

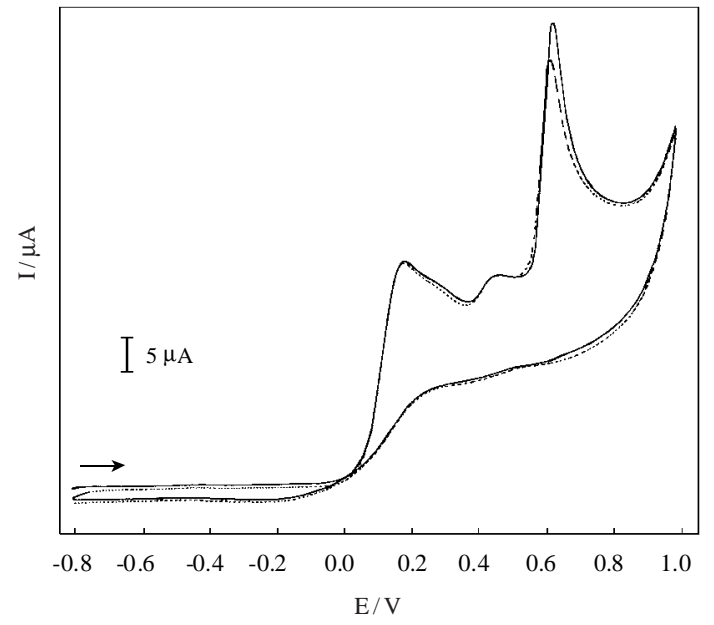

Figure 1. Cyclic voltammogram of $\left[\mathrm{W}(\mathrm{CO})_{4}(\right.$ bipy $\left.)\right]$ (1) in dimethylformamide containing $0.5 \mathrm{~mol} \mathrm{~L}^{-1} \mathrm{NaClO}_{4}$ and $1.0 \times 10^{-3} \mathrm{~mol} \mathrm{~L}^{-1}$ of the complex, $\mathrm{v}=0.05 \mathrm{~V} \mathrm{~s}^{-1}$, at $25{ }^{\circ} \mathrm{C}$; 1 st $\operatorname{scan}(-)$ and $2 \underline{\text { nd }}$ scan (---).

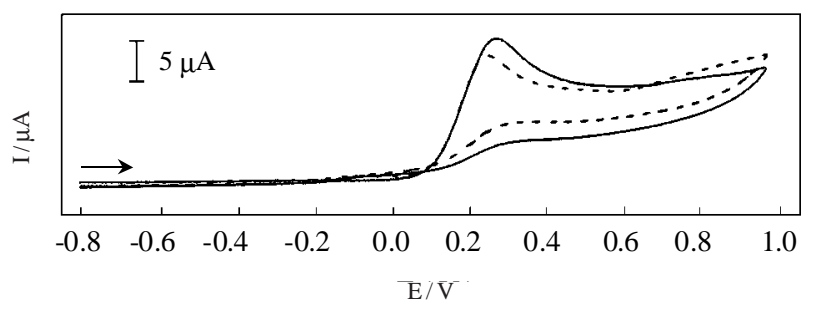

Figure 2. Cyclic voltammogram of $\left[\mathrm{W}(\mathrm{CO})_{3}(\right.$ bipy $\left.)(\mathrm{dppm})\right](2)$ in dimethylformamide containing $0.5 \mathrm{~mol} \mathrm{~L}^{-1} \mathrm{NaClO}_{4}$ and $1.0 \times 10^{-3}$ mol L-1 of the complex, $\mathrm{v}=0.05 \mathrm{~V} \mathrm{~s}^{-1}$, at $25 \mathrm{oC}^{-} 1$ st scan (-) and 2 nd scan (---).

$\mathrm{Ep}_{\mathrm{a}}{ }^{1}$ (Table 2) for compounds $\mathbf{1}$ and $\mathbf{2}$ were attributed to the oxidation of the tungsten atom.

The cyclic voltammogram of compound $\mathbf{3}$ exhibited in the first scan two anodics peaks (1a, 2a ) and one cathodic peak $3 c$. The repetitive scanning revealed the presence of an anodic peak at a more negative potential (3a), which corresponded to the cathodic peak at $3 \mathrm{c}$. A second anodic peak at more positive value (4a) was also found.

In order to elucidate the origin of the pair of peaks $3 \mathrm{c}-$ $3 \mathrm{a}$ the potential scan was reversed before reaching the potential $2 \mathrm{a}$, and consequently the $3 \mathrm{c}$ peak was not observed. Moreover during the second scan the intensity of the $2 \mathrm{a}$ 
peak decreased while the pair of peaks 3c-3a increased. This suggests that the species responsible for the $3 c-3 a$ are associated to the product generated in $2 \mathrm{a}$. The peak separation is around $0.060 \mathrm{~V}$ and the peak current ratio is unity, as expected for a one electron reversible process. The observed redox current peaks were assigned to the oxidation of the ferrocenium nucleus present in dppf ligand ${ }^{20}$.

These results suggest that the $1 \mathrm{a}$ and $2 \mathrm{a}$ peaks are related to the oxidation of the tungsten and iron atoms, respectively. Furthermore the cyclic voltammogram for 3, allowed to consider that this complex also exhibited initially an irreversible oxidation process.

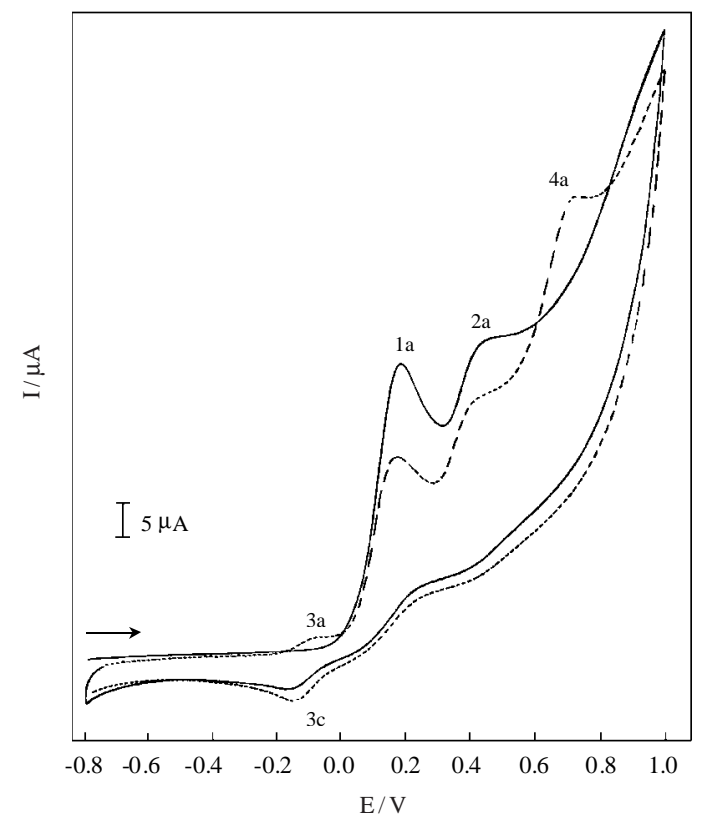

Figure 3. Cyclic voltammogram of $\left[\mathrm{W}(\mathrm{CO})_{3}(\mathrm{bipy})(\mathrm{dppf})\right](3)$ in dimethylformamide containing $0.5 \mathrm{~mol} \mathrm{~L}^{-1} \mathrm{NaClO}_{4}$ and $1.0 \times 10^{-3}$ mol L-1 of the complex, $\mathrm{v}=0.05 \mathrm{~V} \mathrm{~s}^{-1}$, at $25 \mathrm{oC}^{\circ}$; st scan $(-)$ and 2 nd scan (---).

According to the electrochemical behaviour commonly observed for the oxidation of the 18 electron tungstencarbonyl complexes, the first step is a one-electron process and the subsequent chemistry of the system depends upon the stability and reactivity of the 17 electron products ${ }^{9}$. A series of compounds $\left[\mathrm{M}(\mathrm{CO})_{3}\right.$ $\left.\left(\eta^{1}-\mathrm{P}-\mathrm{P}\right)\left(\eta^{2}-\mathrm{P}-\mathrm{P}\right)\right], \mathrm{M}=\mathrm{Cr}, \mathrm{Mo}, \mathrm{W} ; \mathrm{P}-\mathrm{P}=\mathrm{dppm}$, upon electrochemical oxidation in dichloromethane and acetone exhibit the isomerization of the 17 electron product and this step is continued by a slowly decomposition process ${ }^{21}$.

These observations indicated that, in our experiments, the species initially produced upon oxidation of compounds 1, 2 and $\mathbf{3}$ could undergo an isomerization process giving other active electrochemical species responsible for the subsequent anodic peaks observed in the cyclic voltammograms.
In addition, after exhaustive electrolysis at $0.40 \mathrm{~V}$ for the complexes $\mathbf{1}$ and $\mathbf{2}$ and at $0.50 \mathrm{~V}$ for complex $\mathbf{3}$ a color change was observed resulting in yellow solutions. Analyses of these solutions by IR spectroscopy showed the disappearance of $v_{\mathrm{CO}}$ and the presence of free bipy and dppm ligands. Furthermore these results indicated that the oxidation of the tungstencarbonyls complexes $\mathbf{1 ,} 2$ and $\mathbf{3}$ led to unstable species that undergo decomposition processes. Hitherto, the results described suggest in all cases a complex electrode process, with an irreversible chemical decomposition reaction of the oxidized species. The global electrode process in dimethylformamide solution yielded, probably, solvated tungsten species and free bipy and dppm ligands for compounds $\mathbf{1}$ and $\mathbf{2}$, respectively. The cyclic voltammogram of the compound $\mathbf{3}$ after exhaustive electrolysis at $0.50 \mathrm{~V}$ exhibited only the peak $4 \mathrm{a}$ and the pair of peaks $3 c-3 a$. The pair of peaks $3 c-3 a$ is ascribed to solvated $\mathrm{Fe}^{2+} / \mathrm{Fe}^{3+}$ pair analogous to a previous results obtained in our research group ${ }^{22,23}$.

A feature to be noted is that the $\mathrm{Epa}^{1}$ value for $\left[\mathrm{W}(\mathrm{CO})_{6}\right]$ differs significantly from the values obtained for complexes $\mathbf{1}, \mathbf{2}$ and $\mathbf{3}$. Thus the substitution of two $\mathrm{CO}$ groups of $\left[\mathrm{W}(\mathrm{CO})_{6}\right]$ for bipy, giving $\mathbf{1}$, decreases the oxidation potential by $0.52 \mathrm{~V}$. However the comparison of the $\mathrm{Epa}^{1}$ values for compounds $\mathbf{1}, \mathbf{2}$ and $\mathbf{3}$ indicates that the substitution of another $\mathrm{CO}$ by a phosphorous atom of dppm and dppf ligands resulted in a little shift of potentials (Table 2).

Summarizing the above results it was seen that the changes in the ligands nature produced a shift in electron density on the metal center which can be probed by electrochemical studies. In this way the substitution of electron withdrawing carbonyl ligand by a stronger electron donor like bipyridine increases the electron density on the metal and consequently lowers the oxidation potential of the complex.

Replacement of another $\mathrm{CO}$ in $\mathbf{1}$ by a phosphine ligand giving $\mathbf{2}$ and $\mathbf{3}$, decreases the electron density on the metal center. The reason is that the phosphines may not only donate electron density to the metal, but may also withdraw electron density through $\pi$-backbonding. The presence of the dppm and dppf ligands coordinated to tungsten atom shifted the anodic peak potential values in the anodic direction, leading therefore to an increase in the oxidation potential compared to 1. This effect is larger for the dppf ligand and this behaviour may be associated with the iron nucleus presents in $\mathbf{3}$.

The comparison between the oxidation potential of the iron atom in free dppf and in complex $\mathbf{3}$ showed that the electrochemical oxidation of iron was eased by coordination of the ligand to the tungsten atom. This fact can be assigned to the ability of the $\mathrm{W}(\mathrm{CO})_{3}$ (bipy) fragment to $\pi$-donate electron density to the dppf ligand. 
In conclusion, this work showed that the stability of the tungstencarbonyl complexes with respect to electrochemical oxidation follows the order $\left[\mathrm{W}(\mathrm{CO})_{6}\right]>\left[\mathrm{W}(\mathrm{CO})_{3}(\right.$ bipy $\left.)(\mathrm{dppf})\right]$ $>\left[\mathrm{W}(\mathrm{CO})_{3}(\right.$ bipy $\left.)(\mathrm{dppm})\right]>\left[\mathrm{W}(\mathrm{CO})_{4}(\right.$ bipy $\left.)\right]$, in accordance with the changes in electron density on the tungsten atom caused by the substitution of the coordinated $\mathrm{CO}$ groups by bipyridine and phosphine ligands.

\section{Acknowledgements}

The authors gratefully acknowledge financial support from FAPESP and CAPES.

\section{References}

1. Casagrande Jr., O. L.; Tomita, K.; Vollet, D. R. Polyhedron 1996, 15, 4179.

2. Luh, T. H. Coord. Chem. Rev. 1984, 255.

3. Ward, M. D. Coord. Chem. Rev. 1992, 115, 1.

4. Bruce, D. W.; O'Hare, D. Inorganic Materials, John Wiley \& Sons Ltd., New York, 1992.

5. Darensbourg, D. J.; Klausmeyer, K. K.; Reibenspies, J. H. Inorg. Chem. 1996, 35, 1535.

6. Mathur, P.; Sekar, P.; Rheingold, A. L.; Liable-Sands, L. M. Organomet. 1997, 16, 142.

7. Bhadbhade, M. M.; Das, A.; Jeffrey, J. C.; Badiola, J. A. N.;Ward,M. D. J. Chem. Dalton Trans. 1995, 2769.

8. Hors, T. S. A. Inorg. Chim. Acta 1987, 128, L3.

9. Bond, A. M.; Colton, R. Coord. Chem. Rev. 1997, 166, 161.
10. Casagrande Jr., O. L.; Tomita, K.; Mauro, A. E.; Vollet, D. R. Polyhedron 1996, 15, 4179.

11. Mauro, A. E.; Casagrande Jr., O. L.; Nogueira, V. M.; Santos, R. H. A. Gambardella, M. T. P.; Lechat, J. R.; Filho, M. F. J. Polyhedron 1993, 12, 297.

12. Assumpção, R. M. V.; Morita,T. Manual de Soluções, Reagentes e Solventes, Edgar Buncher, São Paulo, 1968.

13. Blagg, A.; Hutton, A. T.; Shaw, B. L.Polyhedron 1987, $6,95$.

14. Adams, D. M. Metal-Ligand and related Vibrations, Edward Arnold, London,1967.

15. Cotton, F. A. Inorg. Chem. 1964, 3, 702.

16. Jenkins, J. M.; Moss, J. R.; Shaw, B. L. J. Chem. Soc. (A). 1969, 2796.

17. Dalton, J.; Paul, I.; Smith, J. G.; Stone, F. G. A. J. Chem. Soc. (A). 1968, 1208.

18. Nixon, J. F.; Pidcock, A. Annu. Rev. NMR Spectrosc. 1969, 3, 345.

19. Alyea, E. C.; Fisher, K. J.; Foo, S.; Philip, B. Polyhedron 1993, 12, 489.

20. Pilloni, G.; Longato, B.; Corain, B. J. Organomet. Chem. 1991, 57, 420.

21. Bond, A. M.; Colton, R.; McGregor, K. Inorg. Chem. 1986, 25, 2378.

22. Nogueira, V.M.; Benedetti, A. V.; Vichi, E. J. S.; Stein, E. J. Electroanal. Chem. 1991, 297, 461.

23. Benedetti, A. V.; Nogueira, V. M.; Vichi, E. J. S.; Stein, E. Quim. Nova 1986, 9, 219.

Received: May 31, 1999.

FAPESP helped in meeting the publication costs of this article. 